\title{
Social Entrepreneurship: A New Genre of Entrepreneurship
}

\author{
Dr. Mir Hossain Sohel ${ }^{1} \&$ Dr. Mohammad Shamsuddoha ${ }^{2}$ \\ ${ }^{1}$ Associate Professor, Department of Marketing, University of Chittagong. \\ ${ }^{2}$ Associate Professor, Western Illinois University, USA \\ *Corresponding author: mirhossainsohel@cu.ac.bd
}

DOI: https://doi.org/10.38157/business-perspective-review.v2i3.58

Citation: Sohel, M. H. \& Shamsuddoha, M. (2020). Social Entrepreneurship: A New Genre of Entrepreneurship. Business Perspective Review 2(3), 60-68. DOI: https://doi.org/10.38157/business-perspective-review.v2i3.58

\section{Research Note}

\begin{abstract}
Purpose: Social entrepreneurship has evolved as a domain of great significance for researchers. The positive impact of social entrepreneurship on alleviating social problems has already been proven. Traditionally, entrepreneurship has been viewed as an entrepreneur's logical response to the opportunities created by the dynamic competitive environment and thus generate profits for individuals or organizations by exploiting the opportunities. This research investigates whether social entrepreneurship is a new genré of entrepreneurship and how it differs from traditional entrepreneurship. Methods: Followed by the archive method of research, this article establishes the legitimacy of social entrepreneurship as a separate academic field and explores several factors, e.g., mission, identification, and exploitation of opportunity, and resource strategy is differentiating social entrepreneurship from its commercial counterparts.

Implications: The study findings would help policymakers develop the institutional framework for supporting the social venture development process and bringing desired policy reforms to encourage social entrepreneurs' sufficient encouragement and motivation.
\end{abstract}

Keywords: entrepreneurship, commercial entrepreneurship, social entrepreneurship.

\section{Introduction}

The current entrepreneurship framework reflects the traditional, capital-first economic model which puts profit maximization over other priorities. The conventional framework considers ecology and society as resources and consumers rather than the business context (Wood, 2014). This traditional model has got enormous achievements and failed simultaneously to achieve the United Nation's Millennium Development Goals, including poverty reduction, action on climate change, and reducing environmental degradation. The current model often brings mistrust among citizens, stakeholders, businesses, and government (Wood, 2014). Social 
entrepreneurship introduces a new breed of entrepreneurs to challenge this ever-increasing income gap and inequalities by improving the community's social, environmental, and economic outcomes (Badulescu, Sipos-Gug, \& Borza, 2013; Kannampuzha \& Hockerts, 2019; J. Mair \& Marti, 2006). This new breed of social entrepreneurs are not born; they are being made (Barendsen \& Gardner, 2004; Elkington \& Hartigan, 2013; Light, 2006). Social entrepreneurs generally build programs and organizations from scratch, rather than refining an existing program or overhauling an organization (Light, 2006).

In recent years there has been a steady growth in the number of social entrepreneurial ventures globally and their interventions in institutional voids or under-served markets are making a significant difference (Bornstein \& Davis, 2010; Drayton, 2006; Gupta, Chauhan, Paul, \& Jaiswal, 2020; Harding \& Cowling, 2006; Kannampuzha \& Hockerts, 2019; Seymour, 2012). This represents the power of social entrepreneurship to address social and environmental issues across the globe, not only those that are primarily in need of economic development (Huda et al., 2019; Kannampuzha \& Hockerts, 2019). Social entrepreneurial ventures are the creative and courageous designers who invent new strategic methods of approaching the social sector to bring effective positive change and transform society. They differ from their other cousins in pursuing visions and championing change and have been defined as change agents, pathbreakers, pioneers, innovators, and activists (Bedi \& Yadav, 2019; Bornstein, 1998; Nicholls, 2006). Social entrepreneurship motivates the entrepreneurs to develop sustainable social enterprise into the framework of society. The prime objective of the social entrepreneurs' in this expedition is to invent new and innovative solutions to social problems with a commitment to make a sustainable social contribution, building social capital, and producing a social profit. Through this, it will improve and transform the quality of life in the society on a local, national, and global level. In short, social entrepreneurs bring positive social change to the human community by creating alternatives to the existing system. This transformation process starts with identifying social issues and creating a vision that will improve social conditions. It also develops an organization to change the system, collectively spreading alternative approaches and then transforming intentions into action by engaging intermediaries of the society towards collectively pursuing positive social change (Hota, Subramanian, \& Narayanamurthy, 2019; Thompson, Alvy, \& Lees, 2000).

The research interest in 'social entrepreneurship' has escalated in the past decade (Dwivedi \& Weerawardena, 2018; Gupta et al., 2020; Kannampuzha \& Hockerts, 2019; Rey-Martí, RibeiroSoriano, \& Palacios-Marqués, 2016). Still, foundational questions need to be answered clearly to ensure the legitimacy of the field (Haugh, 2005; Rey-Martí et al., 2016; Trivedi, 2010). However, social entrepreneurship is defined in different dimensions. For example, some researchers defined social entrepreneurship as non-profit organizations (Lasprogata \& Cotten, 2003), income-generating for-profit ventures run by the non-profit (Wallace, 1999) while some defined it as an organization created at a financial loss (Baron, 2007). Some scholars relate social entrepreneurship with philanthropy (Ostrander, 2007) while others prefer to define social entrepreneurship with a broader dimension relating it to the individuals or organizations adopting entrepreneurial thoughts with a social goal (Certo \& Miller, 2008; Van de Ven, 
Sapienza, \& Villanueva, 2007). A unified definition of social entrepreneurship is yet to develop (Christie \& Honig, 2006; Weerawardena \& Mort, 2006). Like entrepreneurship, in its early days as a field of scholarly endeavor, social entrepreneurship research is still mostly phenomenondriven. As a result, most of the studies in this academic area are based mainly on anecdotal evidence or case studies (Alvord, Brown, \& Letts, 2004; Dey \& Steyaert, 2012; Ismail, Sohel, Kohar, \& Ramliy, 2011). This is due to the field's inherent complexity, making it challenging to map its conceptual boundaries and the lack of available literature in the area. The study, therefore, seeks to address two interrelated questions: Is social entrepreneurship a new genré of entrepreneurship? And how, if at all, does it differ from traditional entrepreneurship? These questions are essential because they can shed further light on the social venture development process's fundamental issues. From a comparative perspective (Rousseau \& Fried, 2001), these questions can help understand the core values and motivational aspects of social entrepreneurship, as social entrepreneurs possess different values and motivations than traditional entrepreneurs. The paper attempts to review existing literature on social entrepreneurship in order to differentiate itself from its counterpart commercial entrepreneurship. The broader impact of the research entails the contribution of distinct, pertinent knowledge regarding 'social entrepreneurship' as a means of societal development, and the origination of new knowledge to improve the government and private sector initiatives and the stakeholder reverberates and networking. The paper also provides some ideas for future research in the field of social entrepreneurship.

\section{Is 'Social Entrepreneurship' Entrepreneurship?}

In the scholarly article "The meaning of social entrepreneurship" (1998), dees mentioned social entrepreneurs as the one special species in the entrepreneurs' genus. So before defining social entrepreneurship, the definition of 'entrepreneurship' needs to be identified.

An examination of the scholarly writings of Richard Cantillon (1680-1734), Jean Baptist Say (1767-1832), and Schumpeter (1883-1950) revealed the definition of an entrepreneur as "...risk taker and innovator, who, when successful, contributes fundamentally to creating economic value" (p.58) (Peredo and McLean, 2006). Tan, Williams, and Tan (2005) defined entrepreneurship as the combination of the entrepreneur's spontaneous response to 'bringing change' and the process of attempting business activities, innovation, and risk-taking to make business profits.

Dees (1998) defined entrepreneurship as combining Say's value creation element and the element of innovation and change from Schumpeter's research. Dees also used Drucker's (1985) research and Stevenson, Roberts, and Grousbeck (1989) to favor his statement. Drucker's research adopted the entrepreneurial activity of recognizing and exploiting opportunities and added the notion of pursuing opportunities regardless of existing resources to entrepreneurship aspects from Stevenson's research. Based on this, Dees identified the entrepreneurial aspects of social entrepreneurship as -

- Recognizing and pursuing new opportunities to create social value,

- Continuous innovation and advancement, adaptation and learning,

- Acting boldly irrespective of resources currently in hand. 
These three elements of recognizing opportunities, continuous innovation, and exhibiting resourcefulness are considered the prime factors to include social entrepreneurship in entrepreneurship. This present study consists of another aspect - the capacity to take the risk, developed by Tan et al. (2005) with the list.

The 'multidimensional model' of social entrepreneurship developed by Mort, Weereawardena, and Carnegie (2003) is perhaps the most effective model till now. Analyzing several scholarly pieces of research (Gartner, 1988; Mintzberg, 1991; Singh, 2001; Stevenson \& Jarillo, 1990; Stevenson et al., 1989) found that social entrepreneurship is the combination of some defining characteristics. According to them, social entrepreneurs -

- "Exhibit a balanced judgment, a coherent unity of purpose and action in the face of complexity"( Mort et al. 2003),

- Recognize opportunities and innovates to take advantage of the opportunity to deliver the social value they are aiming for, and finally

- Like commercial entrepreneurs, they also display risk-taking, continuous innovation, and pro-activeness in their entrepreneurial setting.

The first characteristic in the list is a unique addition that goes beyond the characteristics of opportunity-recognition, risk-tolerating, innovativeness, and resourcefulness, suggested by the earlier researchers on social entrepreneurship. The characteristic tells that social entrepreneurs create social value keeping a balance between multiple stakeholders' interests and moral complexity. The other elements suggested are similar to the aspects of entrepreneurship developed by the earlier researchers.

Given the above explanation, it can be said that social entrepreneurship is very much similar to traditional entrepreneurship with specific very unique characteristics differentiating them both. The features of 'relentless' pursue new opportunities, continuous innovation, learning, risktaking, pro-activeness, and resourcefulness has been echoed in the earlier researches done (Dees, 2007; Drucker, 1985; Peredo \& McLean, 2006), which brings social entrepreneurship under the same roof of traditional entrepreneurship.

\section{Social Vs. Commercial Entrepreneurship}

Entrepreneurship generally focuses on new value creation (Alvarez \& Barney, 2007). Traditional entrepreneurship theories have focused on the risk-orientation of individuals seeking profit (Kirzner, 1973; Schumpeter, 1942). The traditional definition of entrepreneurs ignores the large number of entrepreneurs who stay away from profits and create new organizations to bring about social changes (Hibbert, Hogg, \& Quinn, 2002; Prabhu, 1999). These entrepreneurs, known as social entrepreneurs, create new, viable socioeconomic structures, relations, institutions, organizations, and practices that bring about social benefits (Fowler, 2000).

Social value creation is the common feature present across all definitions of social entrepreneurship and considered to be the central driver of the entrepreneurial process rather than creating individual or shareholders wealth (Thake \& Zadek, 1997) and the process is activated by innovation or creating or introducing something new (Shane \& Venkatraman, 2000) 
rather than imitating or replicating existing practices. So social entrepreneurship features include:

- Creating social value is the central criterion of the process,

- The process is initiated by the innovation or introduction of something new to satisfy the unmet needs,

- The decision on organizational formation will be based on a format that can ensure the mobility of resources to address the problem.

Social entrepreneurship somewhat looks like traditional entrepreneurship with some rudimentary differences (Dhesi, 2010). Entrepreneurship generally involves three elements: opportunities, entrepreneur, and resourcefulness. Therefore, entrepreneurship involves the concurrent existence of lucrative opportunities and of enterprising individuals (Eckhardt \& Shane, 2003; Venkataraman, 1997) which is also an essential characteristic of social entrepreneurship. Both of them use continuous innovation, discipline, determination, adaptation, and learning as their mode of operation (Dees, 1998).

The fundamental differences between social and commercial entrepreneurship lie in the following aspects:

- Organizational mission: Social value creation is the central driving force of the social entrepreneurship process. On the contrary, commercial entrepreneurship aims at making economic profit resulting in individual or shareholders benefit. But this difference is, of course, overstated. The term "social" in social entrepreneurship doesn't make it noteworthy entrepreneurship activities as "less social" or even "non-social". Commercial entrepreneurship also benefits society through conceptualizing new products or services, generating new job opportunities, and most importantly, indirect social transformation. This 'social transformation' can be an important driving force for commercial entrepreneurs. The fundamental distinguishing feature between the two is the difference in mission - the first and foremost concern of social entrepreneurship is social value creation whereas commercial entrepreneurship aims to generate economic gains and may create social value as the by-product of the process (Austin et al., 2006).

- Entrepreneurial opportunity: Entrepreneurial opportunities can be defined as the opportunity to introduce new products, services, ideas, inputs, or organizing methods to bring economic profit (Johanna Mair \& Marti, 2004). According to them, the central way to differentiate social and commercial entrepreneurship is to identify opportunities. This differentiation occurs due to the difference in the mission of these two forms of entrepreneurship. Social entrepreneurship uses innovative ways to bring sustainable social change and brings business and nonprofit- both organizational cultures under one innovative and hybrid organization. In this sense, although social opportunities arise from unsatisfied needs (maybe social or not), and both social and commercial entrepreneurial ventures operate on cash flow and revenue streams, but SE process emphasizes meeting the social need sustainably and thus alleviate social problems rather than on maximizing stakeholders economic value like the commercial entrepreneurship. The social needs are not limited to any particular category, e.g., poverty alleviation, 
global warming, etc. Rather, these needs are more related to enhancing social conditions and bringing social change.

- The exploitation of opportunity: In commercial entrepreneurship, entrepreneurial opportunity exploitation depends on economic profit. The choice of exploitation mode is related to the possibility of enjoying the 'first-ever' benefit as long as possible to ensure more economic returns. The life span of the benefit must be accelerated by controlling others' ability to imitate or substitute or leap-frogging the innovation (Shane and Venkatraman, 2000). But social entrepreneurship overturns this mechanism. In the case of social entrepreneurship, the decision to exploit opportunities depends on the possibility of generating social benefit (at large) and economic gain (to some extent) simultaneously. The success of exploitation depends mainly on jellying social innovation as much as possible to maximize its social impact apart from achieving a competitive economic advantage (Drayton, 2002).

- Resource strategy: According to Austin et al. (2006), human and financial resources are the two most important resources required by a social entrepreneur, similar to commercial entrepreneurs. The difference lies in the acquisition and mobilization of the resources in both forms of entrepreneurship. The social entrepreneurs are rarely able to pay the competitive market rates for critical hiring due to their economic conditions and emphasize heavily the non-financial compensation of the work to attract and retain talent. At the same time, commercial entrepreneurs rely heavily on financial compensation and incentives to do the same. Social ventures are embedded in the motive of balancing social impact and economic sustainability (Desa \& Kotha, 2006) and non-distributive restriction of surpluses (Austin et al., 2006). They often refrain from having financial investments from traditional sources such as venture capitalists and corporate venture funds, which are the main sources of investment for commercial entrepreneurs. Social entrepreneurs have to rely heavily on non-traditional sources of financing like donations, fundraising through volunteers, partnerships or alliances, price discounts, etc., to meet their financial resource requirements.

- Human capital: As the objectives and the value creation process differ between social and commercial entrepreneurs - they may require different skills and capabilities (Estrin, Mickiewicz, \& Stephan, 2016). It infers the types of entrepreneurs that cannot be drawn from the same pool of talent. Both types of entrepreneurs require entrepreneurshipspecific skills and knowledge, social entrepreneurship demands additional abilities in identifying and exploiting opportunities; they can generate positive social impact firmly embedded in local communities (Stephan, Uhlaner, \& Stride, 2015) as well as the conflict between social and economic logic of their enterprise (Battilana \& Lee, 2014).

- Performance measurement mechanism: Commercial and social entrepreneurship differ dramatically in terms of performance measurement due to their differences in mission (Austin et al., 2006). Commercial entrepreneurs' mission is to generate economic profit to make the venture alluring to the investors and stakeholders. Generally, commercial entrepreneurship performance is measured in terms of financial performance (i.e. 
profitability, sales growth, ROI, etc.). These financial performance metrics are standardized and easily recognized and appreciated by entrepreneurs and investors. On the other hand, the social entrepreneurs' mission is to create social value sustainably to alleviate social problems. A common yardstick is yet to develop to measure the social return on investment (Guclu, Dees, \& and Anderson, 2002). Using profitability to measure performance would not prove beneficial, as the social venture's mission is not to maximize monetary gains. It is almost impossible to convert most of the social impacts into quantitative terms (Guclu et al., 2002) like improved self-esteem or reading skills of children. Some social impacts can be measured like a better literacy rate or less pollution. Developing performance measurement mechanisms in order to alleviate the limitation is necessary to establish social entrepreneurship as a separate academic field (J. Mair \& Marti, 2006).

\section{Conclusion and Directions for Future Research}

The study's objective was to establish social entrepreneurship as a new type of entrepreneurship that falls at the intersection of two fields - entrepreneurship and social development. The above findings show that both forms of entrepreneurship use innovative ways to ensure economic and social gain, but only social entrepreneurship prioritizes the objective of positive social gain which conforms to the unique characteristic of social entrepreneurship. Social entrepreneurship is different from its commercial counterpart based on six components - i) organizational mission, ii) entrepreneurial opportunity, iii) exploitation of opportunity, iv) resource strategy, v) human capital, and vi) performance measurement mechanism. It adds new knowledge to the entrepreneurship research in the context of new and emerging social ventures. Although social entrepreneurship is receiving considerable practitioner interest recently but still prevails the scope of future research. The various aspects of the venture development process, ensuring double bottom lines of social and economic gains, performance measurement tools, etc. to establish itself as a separate academic field from entrepreneurship. The researchers hope that future studies, both conceptual and empirical, might answer the study's unresolved questions. It is an area of future research to extend the knowledge base related to entrepreneurship.

Acknowledgment: The authors' are grateful to the Universiti Teknologi Malaysia for their generous support with the research program. VOT No. $02 \mathrm{H} 08$

Authors' Contributions: Both the authors have equally contributed to the preparation of the article.

Conflict of Interest: The authors declare no conflict of interest.

\section{REFERENCES}

Alvarez, S. A., \& Barney, J. B. (2007). Discovery and creation: Alternative theories of entrepreneurial action. Strategic entrepreneurship journal, 1(1-2), 11-26.

Alvord, S. H., Brown, L. D., \& Letts, C. W. (2004). Social entrepreneurship and societal transformation. The Journal of Applied Behavioral Science, 40(3), 260-282. 
Badulescu, A., Sipos-Gug, S., \& Borza, A. (2013). Environmental Obstacles and Support Factors of Social Entrepreneurship. Paper presented at the Proceedings for the 8th Europen Conference on Innovation and Entrepreneurship: ECIE 2013.

Barendsen, L., \& Gardner, H. (2004). Is the social entrepreneur a new type of leader? Leader to leader, 2004(34), 43-50.

Baron, D. P. (2007). Corporate social responsibility and social entrepreneurship. Journal of Economics \& Management Strategy, 16(3), 683-717.

Battilana, J., \& Lee, M. (2014). Advancing research on hybrid organizing-Insights from the study of social enterprises. Academy of Management Annals, 8(1), 397-441.

Bedi, H. S., \& Yadav, N. (2019). Social Entrepreneurship: A Conceptual Clarity. Bedi, HS \& Yadav, N., Social Entrepreneurship: A Conceptual Clarity. Our Heritage, 67(10), 1006-1016.

Bornstein, D. (1998). Changing the world on a shoestring. The Atlantic Monthly, 281(1), 34-39.

Bornstein, D., \& Davis, S. (2010). Social entrepreneurship: What everyone needs to know: Oxford University Press, USA.

Certo, S. T., \& Miller, T. (2008). Social entrepreneurship: Key issues and concepts. Business Horizons, 51(4), $267-271$.

Christie, M. J., \& Honig, B. (2006). Social entrepreneurship: New research findings. Journal of World Business, 41(1), $1-5$.

Dees, J. G. (1998). Enterprising nonprofits. Harvard business review, 76, 54-69.

Dees, J. G. (2007). Taking social entrepreneurship seriously. Society, 44(3), 24-31.

Desa, G., \& Kotha, S. (Eds.). (2006). Technology Social Venture and innovation: Process at Benetech. Cheltenham, UK: Edward Elgar Publishing Ltd.

Dey, P., \& Steyaert, C. (2012). Social entrepreneurship: critique and the radical enactment of the social. Social Enterprise Journal, 8(2), 90-107. doi:10.1108/17508611211252828

Dhesi, A. S. (2010). Diaspora, Social entrepreneurs, and community development. International Journal of Social Economics, 37(9), 703-716.

Drayton, W. (2002). The Citizen Sector: Becoming as entrepreneurial and competitive as business. California Management Review, 44(3), 120-132.

Drayton, W. (2006). Everyone a changemaker: social entrepreneurship's ultimate goal. Innovations: Technology, Governance, Globalization, 1(1), 80-96.

Drucker, P. F. (1985). Innovation and Entrepreneurship. New York: Harper Collins.

Dwivedi, A., \& Weerawardena, J. (2018). Conceptualizing and operationalizing the social entrepreneurship construct. Journal of Business Research, 86, 32-40.

Eckhardt, J. T., \& Shane, S. A. (2003). Opportunities and Entrepreneurship. Journal of Management, 29(3), 333-349.

Elkington, J., \& Hartigan, P. (2013). The power of unreasonable people: How social entrepreneurs create markets that change the world: Harvard Business Press.

Estrin, S., Mickiewicz, T., \& Stephan, U. (2016). Human capital in social and commercial entrepreneurship. Journal of Business Venturing, 31(4), 449-467.

Gartner, W. B. (1988). Who is an entrepreneur? is the wrong question. American journal of small business, 12(4), 11-32.

Guclu, A., Dees, J. G., \& and Anderson, B. B. (2002). 'The process of social entrepreneurship: Creating opportunities worthy of serious pursuit'. Center for the Advancement of Social Entrepreneurship, The Fuqua School of Business.

Gupta, P., Chauhan, S., Paul, J., \& Jaiswal, M. (2020). Social entrepreneurship research: A review and future research agenda. Journal of Business Research.

Harding, R., \& Cowling, M. (2006). Social entrepreneurship monitor. London Business School, Global Entrepreneurship Monitor.

Haugh, H. (2005). A research agenda for social entrepreneurship. Social Enterprise Journal, 1(1), 1-12.

Hibbert, S. A., Hogg, G., \& Quinn, T. (2002). Consumer response to social entrepreneurship: The case of the Big Issue in Scotland. International Journal of Nonprofit and Voluntary Sector Marketing, 7(3), 288-301.

Hota, P. K., Subramanian, B., \& Narayanamurthy, G. (2019). Mapping the intellectual structure of social entrepreneurship research: A citation/co-citation analysis. Journal of Business Ethics, 1-26. 
Huda, M., Qodriah, S. L., Rismayadi, B., Hananto, A., Kardiyati, E. N., Ruskam, A., \& Nasir, B. M. (2019). Towards cooperative with competitive alliance: Insights into performance value in social entrepreneurship. In Creating business value and competitive advantage with social entrepreneurship (pp. 294-317): IGI Global.

Ismail, K. B., Sohel, M. H., Kohar, U. H. A., \& Ramliy, M. (2011). Can Austin's Model of Social Entrepreneurship Ensure Success in Asian Perspective? Australian Journal of Basic \& Applied Sciences, 5(12).

Kannampuzha, M., \& Hockerts, K. (2019). Organizational social entrepreneurship: scale development and validation. Social Enterprise Journal.

Kirzner, I. M. (1973). Entrepreneurship and competition. In: Chicago: University of Chicago Press.

Lasprogata, G. A., \& Cotten, M. N. (2003). Contemplating" Enterprise": The Business and Legal Challenges of Social Entrepreneurship. American Business Law Journal, 41(1), 67-114.

Light, P. C. (2006). Reshaping social entrepreneurship. Stanford Social Innovation Review, 4(3), 47-51.

Mair, J., \& Marti, I. (2004). Social Entrepreneurship: What are We Talking About? A framework for future research. Working paper. IESE Business School, University of Navarra

Mair, J., \& Marti, I. (2006). Social entrepreneurship research: A source of explanation, prediction, and delight. Journal of World Business, 41(1), 36-44.

Mintzberg, H. (1991). The effective organization: forces and forms. Sloan Management Review, 54.

Mort, G. S., Weereawardena, J., \& Carnegie, K. (2003). Social Entrepreneurship: Towards Conceptualization. International Journal of Nonprofit and Voluntary Sector Marketing, 8(1), 76-88.

Nicholls, A. (2006). Social entrepreneurship: new models of sustainable social change: Oxford University Press, USA.

Ostrander, S. A. (2007). The growth of donor control: Revisiting the social relations of philanthropy. Nonprofit and Voluntary Sector Quarterly, 36(2), 356.

Peredo, A. M., \& McLean, M. (2006). Social entrepreneurship: A critical review of the concept. Journal of World Business, 41(1), 56-65.

Prabhu, G. N. (1999). Social entrepreneurship leadership. Career Development International, 4(3), 140-145.

Rey-Martí, A., Ribeiro-Soriano, D., \& Palacios-Marqués, D. (2016). A bibliometric analysis of social entrepreneurship. Journal of Business Research, 69(5), 1651-1655.

Rousseau, D. M., \& Fried, Y. (2001). Location, location, location: Contextualizing organizational research. Journal of organizational behavior, 1-13.

Schumpeter, J. A. (1942). Socialism, capitalism, and democracy: Harper and Bros.

Seymour, R. G. (2012). Handbook of research methods on social entrepreneurship: Edward Elgar Publishing.

Shane, S., \& Venkatraman, S. (2000). The promise of entrepreneurship as a field of research. Academy of Management Review, 25(1), 217-226.

Singh, R. P. (2001). A comment on developing the field of entrepreneurship through the study of opportunity recognition and exploitation. Academy of Management Review, 26(1), 10-12.

Stephan, U., Uhlaner, L. M., \& Stride, C. (2015). Institutions and social entrepreneurship: The role of institutional voids, institutional support, and institutional configurations. Journal of International Business Studies, 46(3), 308-331.

Stevenson, H. H., \& Jarillo, J. C. (1990). A paradigm of entrepreneurship: entrepreneurial management. Strategic management journal, 11(5), 17-27.

Stevenson, H. H., Roberts, M., \& Grousbeck, H. I. (1989). Business ventures and the entrepreneur. Irwin, Homewood, IL.

Tan, W. L., Williams, J., \& Tan, T. M. (2005). Defining the 'social' in 'social entrepreneurship': Altruism and entrepreneurship. International Entrepreneurship and Management Journal, 1(3), 353-365.

Thake, S., \& Zadek, S. (1997). Practical people, noble causes. London: New Economics Foundation.

Thompson, J., Alvy, G., \& Lees, A. (2000). Social entrepreneurship-a new look at the people and the potential. Management Decision, 38(5), 328-338.

Trivedi, C. (2010). Towards a social-ecological framework for social entrepreneurship. The Journal of Entrepreneurship, 19(1), 63-80.

Van de Ven, A. H., Sapienza, H. J., \& Villanueva, J. (2007). Entrepreneurial pursuits of self and collective interests. Strategic entrepreneurship journal, 1(3-4), 353-370. 
Venkataraman, S. (Ed.) (1997). The distinctive domain of entrepreneurship research (Vol. 3). Greenwich: CT: Jai Press.

Wallace, S. L. (1999). Social entrepreneurship: The role of social purpose enterprises in facilitating community economic development. Journal of Developmental Entrepreneurship, 4(2), 153-174.

Weerawardena, J., \& Mort, G. S. (2006). Investigating social entrepreneurship: A multidimensional model. Journal of World Business, 41(1), 21-35.

Wood, M. W. (2014). Addressing Sustainability in an Entrepreneurship Ecosystem: A Case Study of a Social Incubator in Mexico. ARIZONA STATE UNIVERSITY, an open-access article distributed under the terms and conditions of the Creative Commons Attribution (CC BY) license (http://creativecommons.org/licenses/by/4.0/). 